\title{
Long term decentralized greywater treatment for water reuse purposes in a tourist facility by Vertical Ecosystem
}

Andrea Zraunig ${ }^{\mathrm{a}, \mathrm{b}}$, Miquel Estelrich ${ }^{\mathrm{c}, \mathrm{d}}$, Heinz Gattringer ${ }^{\mathrm{a}}$, Johannes Kisser ${ }^{\mathrm{a}}$, Günter Langergraber $^{\mathrm{e}}$, Manfred Radtke ${ }^{\mathrm{f}}$, Ignasi Rodriguez-Roda ${ }^{\mathrm{c}, \mathrm{g}}$, Gianluigi Buttiglieri ${ }^{\mathrm{c}, \mathrm{d}}$

a alchemia-nova $\mathrm{GmbH}$, institute for innovative phytochemistry \& closed loop processes, Baumgartenstraße 93, A-1140 Vienna, Austria

$b$ Institute of Soil Research, BOKU - University of Natural Resources and Life Sciences, Konrad Lorenz Straße 24, A-3430 Tulln an der Donau, Austria

c ICRA, Catalan Institute for Water Research, Emili Grahit 101, E-17003 Girona, Spain

d Universitat de Girona, Girona, Spain

e Institute of Sanitary Engineering and Water Pollution Control, BOKU - University of Natural Resources and Life Sciences, Muthgasse 18, A-1190 Vienna, Austria

$f \quad$ Radtke Biotechnik, Egerlandstraße 16, D-97209 Veitshöchheim, Germany

$g$ LEQUiA, Laboratory of Chemical and Environmental Engineering, University of Girona, Carrer Pic de Peguera 15, E-17003 Girona, Spain

\section{Abstract}

A horizontal flow wetland (HF) was integrated, in a cascading vertical set-up (vertECO), in a Mediterranean tourist facility for decentralized treatment of real low load greywater streams. 15 different plant species were tested in LECA substrate at three different hydraulic retention times (HRTs: 1.9, 1.4 and 1.0 days) with additional aeration improving degradation processes. Beyond standard parameters, several organic micropollutants (14 pharmaceutical organic compounds and 12 endocrine disruptive compounds) were monitored over a 22 month period. The removal efficiency for standard parameters was very high, on average more than $90 \%$ for many parameters (COD, BOD , , TSS, VSS and turbidity) and more than $80 \%$ for TOC. $\mathrm{BOD}_{5}$ removal could be correlated with the temperature, while TN, TKN and $\mathrm{NH}_{4}{ }^{+}-\mathrm{N}$ showed the highest removal efficiency at the lowest HRT. The effluents consistently met the standards for various reuse applications, at all three HRTs, according to Spanish Legislation (RD, 1620/2007) and EU draft. In terms of organic micropollutants, influent greywater was characterized by high concentrations and variability (for example up to $256.1 \pm 875.3 \mu \mathrm{g} \mathrm{L}^{-1}$ for acetaminophen, $88.7 \pm 424.5$ $\mu \mathrm{g} \mathrm{L}^{-1}$ for ibuprofen). More than $95 \%$ of removal by vertECO was achieved for most of the compounds (acetaminophen, ibuprofen, salicylic acid, caffeine, estradiol, progesterone, testosterone, triclosan, methyl-, ethyl- and propylparaben) and more than $80 \%$ for diclofenac, atenolol and trimethoprim. On the other hand, 
hydrochlorothiazide, sulfamethoxazole and salbutamol could not be reduced by more than $30 \%$. Statistically significant differences were found at different HRTs for acetaminophen, atenolol, ibuprofen, ethylparaben, TCPP and TBEP $(p<0.05)$. Conversely, most of the evaluated micropollutants were consistently removed without apparent influence from temperature.

\section{Keywords (6)}

Constructed wetland, vertical ecosystem, horizontal flow, greywater, pharmaceutical active compounds, endocrine disrupting compounds

\section{Introduction}

Mass tourism is a global phenomenon and one of the largest and fastest growing economic sectors in the world. Tourism water consumption is normally less than $5 \%$ of domestic water consumption, but may be as high as $40 \%$ in certain countries e.g. Mauritius (Gössling et al., 2012). In fact, in the last thirty years, the frequency of droughts and the related environmental and economic damage has increased (EC, 2012). As a result, water scarcity is increasing in areas such as the Mediterranean coastal regions, one of the most important tourism destinations in the world. In tourist facilities the water consumption is usually high, 150 to 600 liters per guest per night, depending on hotel category, seasonal fluctuations during high season and weekends (Gabarda-Mallorquí et al., 2017; Gössling et al., 2012). Additionally, tourism can also have a strong impact on the water quality (Moreno-González et al., 2015).

Decentralized treatment systems could be an interesting option in the context of water reuse and therefore reduction in freshwater consumption. Possible tested solutions focus on separate water streams: black water and/ or greywater treatment. In particular, greywater has received attention, because it is less organically polluted than domestic wastewater (including toilet water), contains far less suspended solids and lower turbidity, and can be treated more efficiently for reuse purposes (Eriksson et al., 2002; Jefferson et al., 2001). The treated water might, in the near future, be reused in Europe for agricultural reuse (Alcalde-Sanz and Gawlik, 2017), but it is already a reality in specific countries (e.g. Spain) also for other industrial, urban, 
environmental and recreational uses (RD, 1620/2007) with divergent water quality requirements established by national and international regulations (Alcalde-Sanz and Gawlik, 2017).

In recent decades, concerns about organic micropollutants in water and the environment, such as pharmaceutical active compounds (PhACs) and endocrine disrupting compounds (EDCs), have increased dramatically (Luo et al., 2014). Due to their low concentration and, in some cases, persistency their removal by conventional sewage treatment technologies is often incomplete (Buttiglieri and Knepper, 2008; Carballa et al., 2017). This may lead to negative consequences for the aquatic life, but also risk for the human health etc. In particular, the concentration of micropollutants in greywater was reported to be even higher than in wastewater, due to the absence of dilution with other water streams (Hernández Leal et al., 2010), but data regarding organic micropollutants in greywater are missing. Due to the lack of information, moreover, micropollutants have been rarely included in water related policies. Recently, the Watch List 2018/840 (EC, 2018) and the previous 2015/495 (EC, 2015) included for the first time, at EU level, antibiotics and hormones, like estrone and estradiol, for European monitoring (Loos et al., 2018). This demonstrates the need for further investigations regarding micropollutants presence and the development of new strategies for their removal towards potential reuse applications. Nonetheless, in most countries, no regulation is present yet regarding environmental and human health risks of micropollutants, concentration limits in water intended for different uses and removal requirements for potential reuse technologies.

Compared to other conventional technologies, constructed wetlands (CWs) are a low energy consumption alternative and economically efficient. Several studies have shown that constructed wetlands meet certain reuse standards (RD, 1620/2007) for standard parameters (Gattringer et al., 2016; Ramprasad and Philip, 2016). In particular, horizontal flow (HF) CWs are suitable for on-site treatment, due to their non-free water surface, but they require large footprints compared to other technologies. Few studies report specific CWs (e.g. GROW - Green Roof-top Water Recycling Systems) for greywater treatment on the roof top of buildings (Avery et al., 2007; Ramprasad et al., 2017). Most of these technologies (e.g. HFCW and GROW systems) were tested with lower hydraulic loading rates (HLRs) and/ or longer hydraulic retention times (HRTs) (Avery et al., 2007; Ramprasad et al., 2017; 
Ramprasad and Philip, 2016). A novel vertical staggered CW (vertECO - vertical ecosystem) was recently developed, in order to face space limitations in urban areas (Gattringer et al., 2016). Finally, only very few studies are available on greywater treatment of micropollutants by means of constructed wetlands, for very few compounds and not treating real greywater (Ramprasad and Philip, 2016; Revitt et al., 2011). Also, to the best of our knowledge, no studies are available on this specific topic, with long-term real greywater treatment and application to touristic infrastructures.

In this study, a building integrated HFCW was designed to treat real greywater for water reuse purpose in a large Euro-Mediterranean resort. The simulated constructed wetland (vertECO) was monitored in terms of organic standard parameters as well as micropollutants (14 PhACs and 12 EDCs). This paper presents a long term monitoring experiment evaluating the influence of hydraulic retention time and temperature on the removal efficiencies of the selected parameters.

\section{Materials and methods}

\subsection{Location}

The experimental pilot plant is located in a Euro-Mediterranean hotel in Lloret de Mar (Spain, 41.698, 2.836), a coastal location with Mediterranean climate. The temperature ranges from $8.6{ }^{\circ} \mathrm{C}$ (average minimum last 40 years) to $20.8{ }^{\circ} \mathrm{C}$ (average maximum last 40 years) and an annual precipitation of $728 \mathrm{~mm}$. This large resort offers 441 air-conditioned rooms. In order to save water, the hotel applies partial reuse of greywater for toilet flushing. Depending on the season, water consumption ranges from 25,000 to $34,000 \mathrm{~m}^{3}$ per year, i.e. an average water consumption of 100 to 135 liters per guest per night, depending on seasons and weekends. The reuse of greywater for toilet flushing is approx. 13,500 to $15,000 \mathrm{~m}^{3}$ of tap water per year, reducing water consumption per guest per night by $80 \%$ (Gabarda-Mallorquí et al., 2017).

\section{2. vertECO technology}


The vertECO (vertical ecosystem) was developed for the treatment of hotel greywater streams. This constructed wetland has a vertical set-up with four cascading stages combined with a horizontal subsurface water flow as shown in Figure 2.1. This vertical arrangement has the purpose of maximizing the length of water flow path through the $\mathrm{CW}$ and the optimal spatial utilization due to space limitation in urban areas. vertECO simulates a natural wetland ecosystem to serve as a greywater filter. The plants are cultivated in a hydroponic system with coarse expanded clay as root substrate and a permanent comparatively high saturated water level.

It has the following dimensions: $4.5 \mathrm{~m}$ long $\times 1.5 \mathrm{~m}$ wide and $2.5 \mathrm{~m}$ high (Figure 2.1.) and is semi-indoor with an encapsulation in winter. Each level has a root-substrate volume of $550 \mathrm{~L}$, for a total substrate volume of $2200 \mathrm{~L}$. Each level is placed $50 \mathrm{~cm}$ above the next level below, the containers having a height of $40 \mathrm{~cm}$ and an average width of $35 \mathrm{~cm}$ (Gattringer et al., 2016). A time-controlled pump is used to intermittently load water from an oxygenated water tank to the top floor of the vertical ecosystem. This water tank serves as a buffer tank and as a pre-treatment tank, which allows continuous load during the day and greywater homogenization. The horizontal sub surface waterflow is meandering through the rhizosphere and is forced by gravity into the next floor (each level is connected to the next level by a $1 / 2$ " hose), whereby a permanently high saturated water level is maintained. There are only minor water level fluctuations caused by the outflow of the lower level of the unit. This is in contrast to a vertical flow system, where the bed is completely drained.

As substrate, light expanded clay aggregate (LECA 8/16) was chosen to promote better biofilm development, due to its large surface area. In addition, the nonbiodegradability of the substrate helps to prevent degradation and clogging. This hydroponic system contains $2 \mathrm{~m}^{3}$ expanded clay substrate. In order to promote aerobic microorganisms for efficient rhizosphere degradation processes, air is continuously pumped through perforated hoses into the bottom area of the containers using a 100 watt air compressor with a nominal capacity of $9000 \mathrm{~L} \mathrm{~h}^{-1}$ at $0.045 \mathrm{MPa}$. Another advantage is the avoidance of anaerobic digestion by sulfatereducing microorganisms and associated odors ( $\mathrm{H}_{2} \mathrm{~S}$ production). 


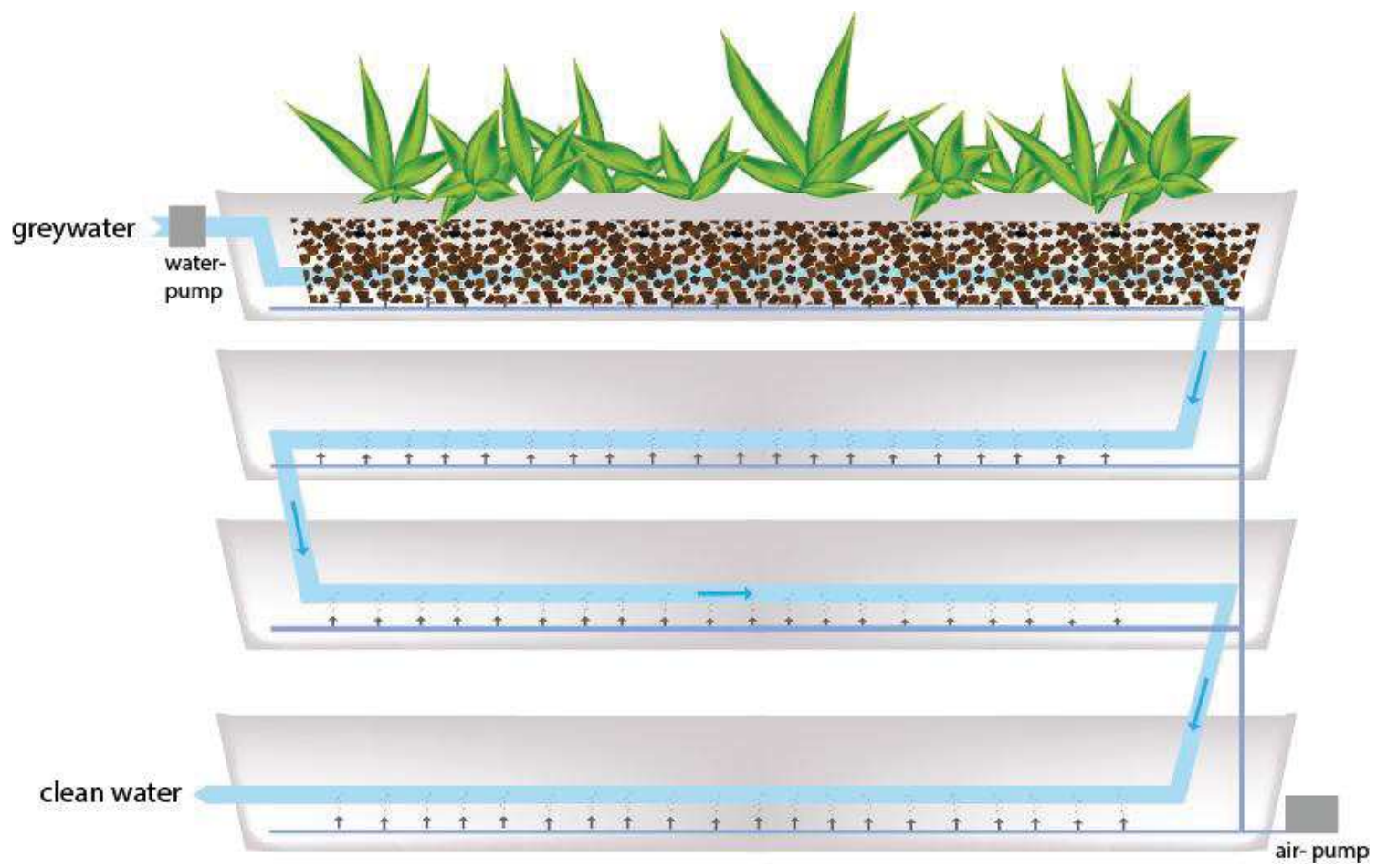

Figure 2.1. Schematic overview of the vertECO technology - all four layers are completely vegetated (planting indicated only in the top floor for a better visualization of water flow pathway and aeration)

Prior to this study, more than 150 emergent plant species were tested in various combinations and adapted to synthetic greywater on laboratory scale. Based on their special growth physiology, that guarantees their survival under difficult rhizosphere conditions (Stottmeister et al., 2003) and their performance, a combination of 15 species (helophytes, graminoids, tropical and subtropical plants, Table 2.1.) are used in the DEMO unit. All stages are fully vegetated with a planting density of approx. 28 plants per $\mathrm{m}^{2}$. For successful plant establishment, a 2 month adaptation phase was allowed prior to the start of the study. 
Table 2.1. Quantity of the selected plant species of the vertECO

\begin{tabular}{clcl}
\hline No & Plant species & No & Plant species \\
\hline 25 & Cyperus alternifolius L. & 6 & Monstera deliciosa LIEBM. \\
15 & Carex acutiformis EHRH. & 36 & Ficus pumila L. \\
10 & Juncus inflexus L. & 9 & Philodendron scandens K.KOCH \& SELLO \\
10 & Juncus effuses L. & 9 & Philodendron erubescens K.KOCH \& AUGUSTIN \\
12 & Equisetum hyemale L. & 20 & Syngonium podophyllum SCHOTT. \\
9 & Spathiphyllum wallisii SCHOTT. & 15 & Iris laevigata FISCH. \& C.A.MEY. \\
9 & Spathiphyllum wallisii 'sensation' SCHOTT. & 5 & Mentha aquatica L. \\
10 & Calathea sp. G.Mey. & & \\
\hline
\end{tabular}

\subsection{Experimental set-up}

The vertECO was fed with real hotel low-load greywater, from the showers and washbasins of the guest rooms. Both urinals and kitchen effluents were not connected to the hotel greywater reuse system and no additional synthetic compounds were added. Influent greywater was characterized, in terms of both, standard parameters and organic micropollutants, as a function of high and low seasons (i.e. periods without encapsulation, with higher environmental temperature, and periods with encapsulation, related to colder periods).

The flow rate was $7 \mathrm{~L} \mathrm{~min}^{-1}$ and the pumping interval was intermittent. During the experimental period, three different flow rates (FR), were applied, as presented in Table 2.2 with the corresponding HRTs, organic loading rates (OLR) and HLRs.

Table 2.2. Operative parameters during the three experimental periods

\begin{tabular}{cccccccc} 
Mode & $\begin{array}{c}\mathrm{FR} \\
{\left[\mathrm{m}^{3} \mathrm{~d}^{-1}\right]}\end{array}$ & $\begin{array}{c}\mathrm{HLR} \\
{\left[\mathrm{m}^{3} \mathrm{~m}^{-2} \mathrm{~d}^{-1}\right]}\end{array}$ & $\begin{array}{c}\text { OLR } \\
{\left[\mathrm{g} \mathrm{COD} \mathrm{m}^{-2} \mathrm{~d}^{-1}\right]}\end{array}$ & $\begin{array}{c}\text { HRT } \\
{[\mathrm{d}]}\end{array}$ & $\begin{array}{c}\text { Temperature } \\
{\left[{ }^{\circ} \mathrm{C}\right]}\end{array}$ & $\begin{array}{c}\text { Sampling } \\
{[\mathrm{n}]}\end{array}$ & $\begin{array}{c}\text { Days } \\
{[\mathrm{d}]}\end{array}$ \\
\hline 1 & 0.750 & 0.10 & 15.9 & 1.9 & $15.2 \pm 5.8$ & 29 & 244 \\
2 & 1.008 & 0.14 & 21.0 & 1.4 & $16.6 \pm 5.0$ & 13 & 184 \\
3 & 1.400 & 0.19 & 34.0 & 1.0 & $18.9 \pm 4.8$ & 20 & 122 \\
\hline
\end{tabular}

Greywater was initially fed once per hour for $4.5 \mathrm{~min}$, resulting in a HLR of $0.10 \mathrm{~m}^{3}$ $\mathrm{m}^{-2} \mathrm{~d}^{-1}$. The inflow was then increased to $6.0 \mathrm{~min}$ and finally to $8.4 \mathrm{~min}$ per hour (corresponding to $0.14 \mathrm{~m}^{3} \mathrm{~m}^{-2} \mathrm{~d}^{-1}$ and $0.19 \mathrm{~m}^{3} \mathrm{~m}^{-2} \mathrm{~d}^{-1}$, respectively).

Inflow and outflow samples of the vertECO were collected and analyzed (for standard parameters and selected micropollutants, section 2.4) towards water reuse according to Spanish Legislation, (RD 1620/2007) and/ or draft European legislation for water reuse (Alcalde-Sanz and Gawlik, 2017). In the present study, only inlet 
(after pre-treatment tank) and outlet (after the technology) were considered to represent the performance of the whole unit itself. The sampling frequency for both standard parameters and micropollutants, divided by period, is presented in Tab.2.2. In the present study, an observation time of 22 months is given.

\subsection{Analytical methods, sample collection and pre-treatment}

Standard chemical parameters and nutrients were analyzed with catalytic oxidation and ion chromatography. Total organic carbon and biochemical oxygen demand were analyzed with catalytic oxidation and respirometry respectively (APHA, 1998). The samples were collected in plastic bottles, with a sample volume of $500 \mathrm{~mL}$ for the inlet and $1000 \mathrm{~mL}$ for the outlet and transported in refrigerated containers. Standard parameters were analyzed on arrival at the research facilities (or frozen at $20^{\circ} \mathrm{C}$, except for the $\mathrm{BOD}_{5}$ parameter, which was always immediately analyzed).

EDCs and PhACs were selected based on micropollutants presence in greywater (Gulyas et al., 2011; Hernández Leal et al., 2010) and based on preliminary sampling campaign (data not shown). A total of 14 PhACs, including analgesics/ anti-inflammatories (6), antibiotics (2), beta blockers (2), contrast media (1), diuretic (1), psychiatric drug (1), receptor antagonist (1) and 12 EDCs and related compounds were analyzed. $125 \mathrm{~mL}$ and $250 \mathrm{~mL}$ were sampled for inlet and outlet in amber PET bottles. For the analyses of micropollutants, the samples were filtered with $0.45 \mu \mathrm{m}$ PVDF membrane filters (Merck Millipore, Germany) and immediately frozen at $-20^{\circ} \mathrm{C}$, until analysis.

\subsubsection{Micropollutants analyses}

All compounds were purchased from Sigma-Aldrich and isotopically labelled compounds were used as internal standards from Toronto Research Chemicals and Cluzeau Info Labo. HPLC-grade methanol, acetonitrile, water (LiChrosolv), ammonium acetate, formic acid and $\mathrm{Na}_{2}$ EDTA were purchased from Merck (Germany). Nitrogen for drying $99.995 \%$ of purity was from Abelló Linde (Spain).

\section{Analysis of pharmaceuticals}

In each sample for pharmaceutical analyses, a suitable volume of $0.1 \mathrm{M} \mathrm{Na}_{2}$ EDTA solution was added to achieve a final concentration of $0.1 \%$ ( $\mathrm{g}$ solute/ $\mathrm{g}$ solution). Samples were pre-concentrated using Oasis HLB cartridges (60 mg, $3 \mathrm{~mL}$ ) (Waters Corp., Milford, MA, USA), which were conditioned with $5 \mathrm{~mL}$ of methanol followed by $5 \mathrm{~mL}$ of HPLC grade water. $25 \mathrm{~mL}$ of the sample was loaded to the cartridge at $1 \mathrm{~mL}$ 
$\mathrm{min}^{-1}$. After sample pre-concentration, cartridges were rinsed with $6 \mathrm{~mL}$ of HPLC grade water and air-dried for $5 \mathrm{~min}$ to remove all water. Analytes were eluted with 6 $\mathrm{mL}$ of pure methanol. Extracts were evaporated to dryness under a gentle nitrogen stream and reconstituted with $1 \mathrm{~mL}$ of methanol. $10 \mu \mathrm{L}$ extract was diluted in $1 \mathrm{~mL}$ of methanol/ water. Finally, $10 \mu \mathrm{L}$ of an internal standard mixture (at $1 \mathrm{mg} \mathrm{L}^{-1}$ ) were added to the extract. Samples were further analyzed using Ultra-PerformanceTM liquid chromatograph system (Waters Corp. Milford, MA, USA) coupled to a quadrupole-linear hybrid ion trap mass spectrometer (5500 QTRAP, Applied Biosystems, Foster City, CA, USA) with a turbo Ion Spray source. Chromatographic separation was carried out using Acquity HSS T3 column (for positive electrospray ionization) and Acquity BEH C18 column (for negative electrospray ionization) (Waters Corp. Milford, MA, USA). The limits of detection were between 0.1 and 5.0 $\mathrm{ng} \mathrm{L}^{-1}$. The detailed procedure of the analysis was as described by Gros et al. (2012). Recoveries, limits of detection (LOD) and limits of quantification (LOQ) are presented in Table $\mathbf{S} 1$.

Analysis of endocrine disruptor and related compounds

Samples were extracted using Strata-X cartridges (200 mg, $6 \mathrm{~mL}$ ) (Phenomenex), conditioned with $5 \mathrm{~mL}$ of methanol followed by $5 \mathrm{~mL}$ of HPLC grade water. Samples $\left(50 \mathrm{~mL}\right.$ ) were loaded at $1 \mathrm{~mL} \mathrm{~min}{ }^{-1}$. Finally, the cartridges were dried under vacuum conditions in order to carry out the elution with a mixture of dichloromethane:methanol (50:50). The extract was reconstituted with $1 \mathrm{~mL}$ of methanol:water and $50 \mu \mathrm{L}$ of internal standard was added. Samples were analyzed by an Ultra Performance Liquid Chromatography (Thermo Fisher Scientific) system coupled to a triple quadrupole mass spectrometer (TSQ Vantage, Thermo Fisher Scientific). Chromatographic separation was carried out using a LUNA OMEGA C18 $1.6 \mu \mathrm{m}(100 \times 2.1 \mathrm{~mm})$ (Phenomenex) column. The limits of detection were between 0.12 and $14 \mathrm{ng} \mathrm{L}^{-1}$. The detailed procedure of the analysis was as described by Gorga et al. (2013). Recoveries, LOD and LOQ are presented in Table S1.

\subsection{Data analysis}

Statistical data evaluation was performed using IBM SPSS 21. The normality and homogeneity of the data were tested with Shapiro-Wilk and Levene's test. When normal distribution and homogeneity of variances of the data were confirmed, a one- 
way ANOVA was performed to compare the removal efficiencies with different water flows. Tukey test was performed as post hoc test for multiple comparison of means. Where it was not possible to use ANOVA, Kruskal-Wallis test was performed. Linear Regression was used to investigate interactions between removal efficiency and temperature. Differences were considered as significant when $p<0.05$.

\section{Results and discussion}

\subsection{Standard parameters}

\subsubsection{Greywater standard parameters characterization}

The average influent greywater composition is presented in Table 3.1. It generally displays results in terms of average $\operatorname{COD}\left(158 \pm 112 \mathrm{mgO}_{2} \mathrm{~L}^{-1}\right)$ and $\mathrm{BOD}_{5}(116 \pm 67$ $\mathrm{mgO}_{2} \mathrm{~L}^{-1}$ ), slightly lower compared to the literature (Jefferson et al., 2004), apparently due to higher observed per capita water consumption, and the corresponding dilution, in touristic infrastructures (Avery et al., 2007; Ramprasad et al., 2017). The calculated COD:BOD ${ }_{5}$ ratio of $1.41 \pm 0.91$ was quite low, indicating an overall good biodegradability, while the COD:TN ratio of $6.85 \pm 19.95$ was appropriate (Eriksson et al., 2002), most probably related to the aeration in the pretreatment tank, forcing nitrification. Compared to other greywater studies (Ramprasad et al., 2017) the concentration of nitrates $\left(\mathrm{NO}_{3}{ }^{-} \mathrm{N}\right)$, nitrites $\left(\mathrm{NO}_{2}{ }^{-} \mathrm{N}\right)$ and phosphates $\left(\mathrm{PO}_{4}^{-} \mathrm{-}\right)$ ) are low $\left(0.02 \pm 0.04,0.06 \pm 0.39\right.$ and $0.34 \pm 0.76 \mathrm{mg} \mathrm{L}^{-1}$, respectively), due to the fact that urinals, kitchen and laundry effluents were not connected to the greywater stream. The extremely low phosphorus content, on the other hand, can be related to the fact that most washing detergents no longer contain phosphates, because of their toxicity, nutrient pollution and consequently algae blooms. Suspended solids to turbidity ratio of $1.40 \pm 2.73$ was low, but in the literature range (Jefferson et al., 2004). Generally, higher concentrations for total suspended solids are related to washing machines and kitchen basins, not included in the hotel greywater of the present study. It is highlighted that the inlet of the technology was sampled after the pretreatment aerated influent tank and, consequently, some degradation and solids sedimentation can be expected (Dixon et al., 1999). 
Finally, electrical conductivity (EC) was more than $700 \mu \mathrm{S} \mathrm{cm}^{-1}$, the main sources being the salts included in soaps, detergents, washing powders and, mainly, the hotel tap water itself with average EC of $600 \mu \mathrm{S} \mathrm{cm}^{-1}$.

Table 3.1. Greywater characterization of influent, effluent (mean values (AV) and STDEV) and removal efficiencies (\%) under different HRTs

\begin{tabular}{|c|c|c|c|c|c|c|c|}
\hline \multirow[t]{2}{*}{ Parameter } & \multirow[t]{2}{*}{ AV influent } & \multirow[t]{2}{*}{ AV effluent } & \multicolumn{4}{|c|}{ Removal Efficiencies [\%] } & \\
\hline & & & AV & $1.9[d]$ & $1.4[d]$ & $1.0[d]$ & \\
\hline $\operatorname{COD}\left(\mathrm{mgO}_{2} \mathrm{~L}^{-1}\right)$ & $158 \pm 112$ & $6 \pm 12$ & $94 \pm 14$ & $92 \pm 16$ & $96 \pm 11$ & $93 \pm 12$ & $*$ \\
\hline $\mathrm{BOD}\left(\mathrm{mgO}_{2} \mathrm{~L}^{-1}\right)$ & $116 \pm 67$ & $3 \pm 3$ & $96 \pm 3$ & $95 \pm 4$ & $96 \pm 2$ & $99 \pm 1$ & $*, t$ \\
\hline TOC $\left(\mathrm{mgC} \mathrm{L}^{-1}\right)$ & $39.0 \pm 25.6$ & $5.5 \pm 2.3$ & $82 \pm 11$ & $78 \pm 11$ & $82 \pm 12$ & $87 \pm 8$ & $*$ \\
\hline TSS $\left(\mathrm{mg} \mathrm{L}^{-1}\right)$ & $63 \pm 114$ & $3 \pm 6$ & $91 \pm 16$ & $88 \pm 17$ & $90 \pm 20$ & $96 \pm 3$ & $*$ \\
\hline VSS $\left(\mathrm{mg} \mathrm{L}^{-1}\right)$ & $53 \pm 82$ & $2 \pm 3$ & $93 \pm 9$ & $91 \pm 10$ & $92 \pm 11$ & $98 \pm 3$ & $*$ \\
\hline Turbidity (NTU) & $68.4 \pm 39.8$ & $1.8 \pm 1.5$ & $96 \pm 6$ & $91 \pm 8$ & $97 \pm 3$ & $96 \pm 7$ & $*$ \\
\hline $\mathrm{EC}\left(\mu \mathrm{S} \mathrm{cm} \mathrm{cm}^{-1}\right)$ & $767 \pm 108$ & $783 \pm 52$ & - & - & - & - & \\
\hline pH & $7.08 \pm 0.31$ & $7.36 \pm 0.29$ & - & - & - & - & $*$ \\
\hline TN $\left(\mathrm{mg} \mathrm{L}^{-1}\right)$ & $10.4 \pm 9.3$ & $4.6 \pm 2.6$ & $43 \pm 40$ & $37 \pm 47$ & $33 \pm 24$ & $60 \pm 34$ & $*, \dagger$ \\
\hline TKN $\left(\mathrm{mg} \mathrm{L}^{-1}\right)$ & $10.3 \pm 9.0$ & $2.4 \pm 2.3$ & $73 \pm 31$ & $69 \pm 36$ & $63 \pm 28$ & $87 \pm 14$ & $*, \dagger$ \\
\hline $\mathrm{NO}_{2}^{-}-\mathrm{N}\left(\mathrm{mg} \mathrm{L}^{-1}\right)$ & $0.06 \pm 0.39$ & $0.10 \pm 0.43$ & - & - & - & - & \\
\hline $\mathrm{NO}_{3}^{-}-\mathrm{N}\left(\mathrm{mg} \mathrm{L}^{-1}\right)$ & $0.02 \pm 0.04$ & $2.31 \pm 1.80$ & - & - & - & - & \\
\hline $\mathrm{NH}_{4}{ }^{+}-\mathbf{N}\left(\mathrm{mg} \mathrm{L}^{-1}\right)$ & $4.88 \pm 2.92$ & $1.55 \pm 1.37$ & $56 \pm 50$ & $52 \pm 29$ & $37.9 \pm 45$ & $67 \pm 53$ & $*, \dagger$ \\
\hline $\mathrm{PO}_{4}^{-}-\mathrm{P}\left(\mathrm{mg} \mathrm{L}^{-1}\right)$ & $0.34 \pm 0.76$ & $0.54 \pm 1.80$ & - & - & - & - & \\
\hline
\end{tabular}

total sample size: $n=58, B^{2} D_{5}: n=50$; turbidity: $n=30$

- effluent mean values $>$ influent mean values

* effluent significantly lower than influent $(p<0.05)$

$\dagger$ significant differences between the different HRTs $(p<0.05)$

$\ddagger$ significant differences between removal efficiency and temperature $(p<0.05)$

\subsubsection{Overall standard parameters removal efficiency}

Organics, suspended solids, ECs and turbidity

vertECO achieved total average removal efficiencies higher than $90 \%$ for COD, $\mathrm{BOD}_{5}$, TSS, VSS and turbidity and more than $80 \%$ for TOC (Table 3.1.). Similar results were reported with GROW systems and HF wetlands by Ramprasad et al. (2017) and Avery et al. (2007), but the latter with less polluted greywater. Compared to other HF systems, vertECO has higher removal efficiencies for $\mathrm{BOD}_{5}$, due to the fact that oxygen is not the limiting factor, since air is actively pumped into the root zone by an air compressor. Additional oxygen release from the roots into the rhizosphere, increasing microbial activity, is also expected, as discussed in other studies (Stottmeister et al., 2003). In contrast to other studies, the high variability and the increase of the organic content in the influent during the monitoring period had no influence on the outlet concentration (Ramprasad et al., 2017). The OLR reached 
$34 \mathrm{~g} \mathrm{COD} \mathrm{m}^{-2} \mathrm{~d}^{-1}$ (depended on the number and behavior of the hotel guests) and it may be assumed that the maximum capacity of the vertECO has not been reached in the present study. Organic removal is mostly related to the rhizosphere associated microbial degradation and adsorption, but sedimentation and filtration may also contribute (Vymazal, 2002). Suspended solids removal, more than $90 \%$, was higher than reported values for Mediterranean areas (72-84\%, Masi and Martinuzzi, 2007) and related mainly to the observed constant climatic conditions and the applied high planting density, resulting in larger sedimentation, root structure filtration and biodegradation processes in the rhizosphere (Vymazal, 2005).

Effluent EC was, as expected, slightly higher than in the influent, due to water loss (evapotranspiration), plant uptake and release (Albalawneh et al., 2016) or salt release from body care products and other products.

\section{Nutrients}

TKN (73\%) and TN (43\%) removal was slightly lower compared to the literature (Langergraber, 2005; Ramprasad et al., 2017). Plants provide optimal rhizosphere conditions for aerobic degradation and nitrification, as well as partial uptake of nitrate and ammonia into their tissues. Moreover, in vertECO the root zone is actively ventilated and consequently nitrification was expected, but not denitrification.

In terms of phosphate $(P)$, no statistically significant difference between influent and effluent concentrations was observed. This can be attributed to the fact that phosphate concentration in the influent was low and possibly even at deficient concentrations for the plants. On the other hand, the plant uptake and adsorption to LECA might have built up a $\mathrm{P}$ reservoir. Consequently, occasional findings of higher phosphate concentrations in the effluent than in the influent can be related to some $P$ release. Although the removal efficiency for nitrate, nitrite and phosphate was limited, it can be noted that the effluent was unproblematic for water reuse and regulatory compliance (RD, 1620/2007) for many purposes.

\subsubsection{Standard parameters removal under different conditions}

Temperature and HRT are two recognized key factors for constructed wetlands operation. Higher temperatures are related to an increase of biodegradation rates and longer HRTs to higher removal efficiencies (Lee et al., 2009). 
During the research period, the water flow was gradually increasing and the corresponding removal efficiencies were compared. As shown in Tab. 3.1., in most cases a higher removal efficiencies of the pollutants were observed by reduced HRT (not statistically significant), in controversy to other studies (Ramprasad et al., 2017). Compared to other HF CW technologies (e.g. Ramprasad et al., 2017), vertECO has a 6 times higher planting density. During the experiment, the root biomass and the corresponding root surface developed well, providing better conditions for rhizosphere associated microorganisms and most likely leading to improved pollutants biodegradation. Similar conclusions can be drawn regarding the removal of suspended solids under different conditions. The reduction of HRT did not affect the removal, the difference with the other periods being not statistically significant. Suspended solids are highly dependent on physical/ mechanical removal, e.g. filter mechanism of denser plant roots, increasing during the experimental period and compensating the increase of HRT itself.

On the other hand, statistical differences were observed for TKN, TN and $\mathrm{NH}_{4}{ }^{+}-\mathrm{N}$ removals at different HRTs, with the highest removal observed at the lowest HRT of $1.0 \mathrm{~d}$. The overall performance was good and with higher applied flow rates compared to other studies (e.g. Ramprasad et al., 2017; 62, 82, 100 and $120 \mathrm{~L} \mathrm{~d}^{-1}$ ). To be highlighted that the lowest HRT was tested at the end of the experiment, with well-developed plants with much higher biomass than 2 years earlier. A better environment for microorganisms, the planting density and the higher demand for $\mathrm{N}$ nutrients by the plants can be claimed to explain these results.

Regarding the possible influence of temperature, only the $\mathrm{BOD}_{5}$ removal was higher $(p<0.05)$ and to be related to higher microbial activity during summer season (Akratos and Tsihrintzis, 2007), although the temperature differences among seasons were not extreme. In general, constructed wetlands in the Mediterranean, with average values not lower than $15{ }^{\circ} \mathrm{C}$, show a better performance compared to the ones applied in temperate climates (Masi and Martinuzzi, 2007).

To be remarked that, also evaluating separately the periods at different HRTs and temperature, all effluent standard parameters successfully complied with the standards of RD, 1620/2007 (Spanish legislation for water reuse) and EU draft for water reuse (Alcalde-Sanz and Gawlik, 2017). 
With regard to pathogens and microbiological contamination, greywater is usually less contaminated compared to wastewater. Previous experiments with vertECO showed a reduction of $\log 2$ to $\log 3$ in populations of Escherichia coli and Intestinal enterococci (Gattringer et al., 2016). These preliminary results indicate possible reuse scenarios for non-direct body contact water. However, further experiments are required to confirm this assumption.

\subsection{Micropollutants}

The results in terms of the presence of micropollutants in greywater and removal by the vertECO are shown in Table 3.2. Since greywater literature is largely missing, studies on wastewater treatment have been considered in some cases for comparison and discussion. Greywater with concentrations of micropollutants higher than in wastewater was previously reported and related to the absence of dilution with storm water and toilet water by a factor 2-4 (Hernández Leal, 2010). It is also worth remarking that the treated greywater in the present study was low-load, without mixing and possible dilution with laundry water or kitchen effluent.

\subsubsection{Micropollutants greywater characterization}

The content of organic micropollutants in the influent greywater was characterized subdividing the results based on the tourist season, (high: summer period, many young visitors; or low: retirees and older people make a much larger proportion of the visitors) and the corresponding fluctuations.

Extremely high concentrations and high variability were observed in hotel greywater for some PhACs like acetaminophen (256.1 $\left.\pm 875.3 \mu \mathrm{g} \mathrm{L}^{-1}\right)$, salicylic acid (58.5 \pm $\left.135.2 \mu \mathrm{g} \mathrm{L}^{-1}\right)$, ibuprofen $\left(88.7 \pm 424.5 \mu \mathrm{g} \mathrm{L}^{-1}\right)$ and diclofenac $\left(38.4 \pm 147.8 \mu \mathrm{g} \mathrm{L}^{-1}\right)$. Results on micropollutants content in greywater are largely lacking and not easily comparable. The here reported high concentrations are in contrast with some previous studies and are only similar to spiked greywater (Ávila et al., 2010). Much lower salicylic acid and acetaminophen concentrations $\left(0.6 \mu \mathrm{g} \mathrm{L}^{-1}\right.$ and $1.5 \mu \mathrm{g} \mathrm{L}^{-1}$, respectively), for example, are usually reported in greywater (Eriksson et al., 2002). Such levels are extremely high even compared to wastewater levels (e.g. CarranzaDiaz et al., 2014; Hijosa-Valsero et al., 2010). 
Very few studies are also available on EDCs with most of them referring only to caffeine and bisphenol A. The concentration of Bisphenol A $\left(0.3 \pm 0.5 \mu \mathrm{g} \mathrm{L}^{-1}\right)$ was comparable to other studies (Hernández Leal et al., 2010) and similar to the plasticizers tris(2-chloroisopropyl)phosphate (TCPP) and tris(2butoxyethyl)phosphate (TBEP). The average caffeine concentration $(16.7 \pm 20.8 \mu \mathrm{g}$ $\left.\mathrm{L}^{-1}\right)$ was slightly higher but comparable to other studies (13.2 $\mu \mathrm{g} \mathrm{L}^{-1}$, Carranza-Diaz et al., 2014). The concentrations of triclosan and the preservatives methyl-, ethyland propylparaben $\left(0.2 \pm 0.5 \mu \mathrm{g} \mathrm{L}^{-1}, 6.9 \pm 8.9 \mu \mathrm{g} \mathrm{L}^{-1}, 3.4 \pm 9.4 \mu \mathrm{g} \mathrm{L}^{-1}\right.$ and $2.2 \pm 2.6$ $\mu \mathrm{g} \mathrm{L}^{-1}$, respectively) were also in the literature order of magnitude (Andersen et al., 2007; Eriksson et al., 2002). Finally, hormones were detected, but at limited concentrations (lower than $0.02 \mu \mathrm{g} \mathrm{L}^{-1}$ ).

For some PhACs, a statistically significant $(p<0.05)$ seasonal variability was observed in the influent greywater (Fig.3.2.1.). During the low touristic season, some PhACs (acetaminophen, diclofenac and ibuprofen) were in fact higher detected than in the high touristic season. This can be related to the variability in the hotel clients composition, changing over the year in terms of age and necessities of disease treatment, and the cold season itself with lower temperature (Kozak and Rimmington, 2000). A reverse trend, possibly also associated to tourist composition variability, was qualitatively observed for caffeine, methyl-, ethyl- and propylparaben, at higher concentrations in the high touristic season (but not statistically different, $p>$ 0.05). 


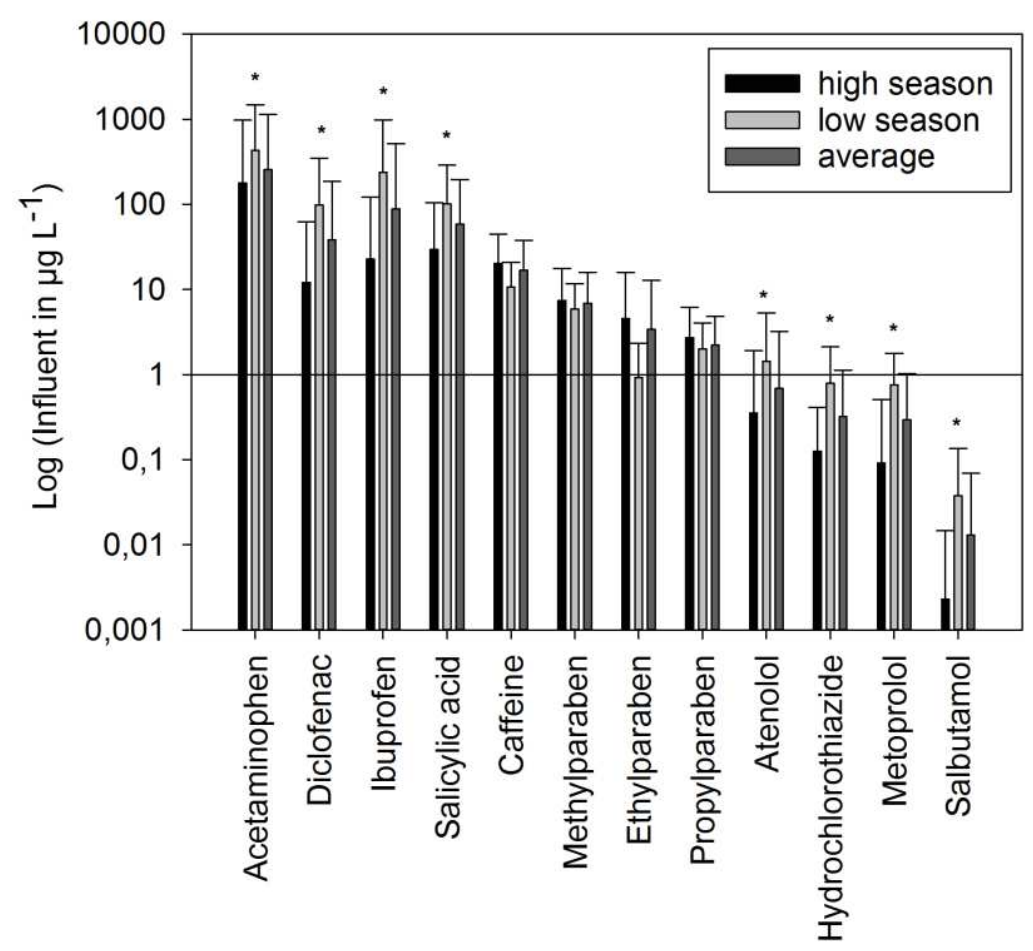

Figure 3.2.1. Micropollutants logarithmic influent concentration (in $\mu \mathrm{g} \mathrm{L}^{-1}$ ) during high season, low season and average. Significant differences $(p<0.05)$ are marked with an asterisk $\left(^{*}\right)$ 
Table 3.2. Micropollutants characterization of influent greywater, vertECO effluent and vertECO removal efficiencies (as average and under different HRTs). AV (mean values).

\begin{tabular}{|c|c|c|c|c|c|c|c|}
\hline \multirow[t]{2}{*}{ Parameter } & \multirow[t]{2}{*}{$\begin{array}{l}\text { AV influent } \\
{\left[\mu g L^{-1}\right]}\end{array}$} & \multirow[t]{2}{*}{$\begin{array}{c}\text { AV effluent } \\
{\left[\mu g L^{-1}\right]}\end{array}$} & \multicolumn{4}{|c|}{ Removal Efficiency [\%] } & \\
\hline & & & AV & $1.9[\mathrm{~d}]$ & $1.4[\mathrm{~d}]$ & $1.0[\mathrm{~d}]$ & \\
\hline \multicolumn{8}{|c|}{ Analgesic anti-inflammatory drugs } \\
\hline Acetaminophen & $256.1 \pm 875.3$ & $0.09 \pm 0.11$ & $98.2 \pm 2.8$ & $96.9 \pm 3.6$ & $98.7 \pm 1.5$ & $99.8 \pm 0.6$ & $*, \dagger$ \\
\hline Diclofenac & $38.4 \pm 147.8$ & $0.61 \pm 0.97$ & $88.0 \pm 20.6$ & $93.6 \pm 14.6$ & $81.1 \pm 18.4$ & $83.1 \pm 27.4$ & $*$ \\
\hline Ibuprofen & $88.7 \pm 424.5$ & $0.30 \pm 1.19$ & $98.3 \pm 3.0$ & $97.9 \pm 3.3$ & $96.6 \pm 3.4$ & $99.8 \pm 0.5$ & $*, \dagger$ \\
\hline Ketoprofen & $0.92 \pm 3.54$ & $0.32 \pm 0.62$ & $66.3 \pm 58.4$ & $53.3 \pm 68.2$ & $41.8 \pm 57.9$ & $77.8 \pm 66.7$ & \\
\hline Naproxen & $0.23 \pm 0.56$ & $0.14 \pm 0.30$ & $60.7 \pm 44.8$ & $49.8 \pm 54.8$ & $77.8 \pm 29.9$ & $17.3 \pm 0.0$ & \\
\hline Salicylic acid & $58.5 \pm 135.2$ & $0.09 \pm 0.08$ & $99.2 \pm 1.2$ & $99.2 \pm 1.0$ & - & $99.3 \pm 1.5$ & $*$ \\
\hline \multicolumn{8}{|l|}{ Antiepileptic drug } \\
\hline Carbamazepine & $1.18 \pm 7.57$ & $0.07 \pm 0.15$ & $56.6 \pm 63.8$ & $28.6 \pm 100.2$ & $40.7 \pm 55.2$ & $83.4 \pm 12.6$ & \\
\hline \multicolumn{8}{|l|}{ Antibiotics } \\
\hline Sulfamethoxazole & $0.06 \pm 0.39$ & $0.05 \pm 0.25$ & $21.7 \pm 53.4$ & $31.1 \pm 85.5$ & $-19.5 \pm 54.3$ & $29.1 \pm 83.1$ & \\
\hline Trimethoprim & $0.06 \pm 0.03$ & $0.02 \pm 0.19$ & $91.1 \pm 21.2$ & $96.1 \pm 15.2$ & $99.9 \pm 0.0$ & $81.7 \pm 28.1$ & $*$ \\
\hline \multicolumn{8}{|l|}{ Beta blockers } \\
\hline Atenolol & $0.69 \pm 2.53$ & $0.01 \pm 0.02$ & $93.2 \pm 8.3$ & $88.5 \pm 9.8$ & $89.9 \pm 6.6$ & $98.9 \pm 3.2$ & $*, \dagger$ \\
\hline Metoprolol & $0.29 \pm 0.72$ & $0.08 \pm 0.26$ & $65.3 \pm 36.9$ & $56.8 \pm 46.4$ & $70.6 \pm 10.7$ & $70.6 \pm 34.9$ & $*$ \\
\hline \multicolumn{8}{|l|}{ Contrast media } \\
\hline Iopromide & $0.003 \pm 0.006$ & $0.00 \pm 0.00$ & $75.0 \pm 68.3$ & $99.9 \pm 0.0$ & $99.9 \pm 0.0$ & $33.3 \pm 103.3$ & $*$ \\
\hline \multicolumn{8}{|l|}{ Diuretics } \\
\hline Hydrochlorothiazide & $0.32 \pm 0.81$ & $0.10 \pm 0.18$ & $28.3 \pm 60.4$ & $13.2 \pm 58.6$ & $26.1 \pm 57.3$ & $51.38 \pm 61.7$ & $*, \ddagger$ \\
\hline \multicolumn{8}{|l|}{ Receptor antagonist } \\
\hline Salbutamol & $0.01 \pm 0.06$ & $0.02 \pm 0.18$ & $-7.6 \pm 96.3$ & $-5.6 \pm 100.5$ & $64.7 \pm 80.7$ & $-51.6 \pm 83.9$ & \\
\hline \multicolumn{8}{|l|}{ Stimulant drugs } \\
\hline Caffeine & $16.7 \pm 20.8$ & $0.73 \pm 2.19$ & $96.2 \pm 7.7$ & $93.9 \pm 11.4$ & $97.0 \pm 2.7$ & $98.2 \pm 2.6$ & $*$ \\
\hline \multicolumn{8}{|l|}{ Hormones } \\
\hline Estrone & $0.02 \pm 0.07$ & $0.004 \pm 0.031$ & $98.9 \pm 0.0$ & $98.5 \pm 3.6$ & n.d. & $99.9 \pm 0.0$ & $*$ \\
\hline Estradiol & $0.001 \pm 0.000$ & $0.00 \pm 0.00$ & $99.9 \pm 0.0$ & $99.9 \pm 0.0$ & n.d. & n.d. & \\
\hline Progesterone & $0.003 \pm 0.010$ & $0.00 \pm 0.00$ & $99.9 \pm 0.0$ & n.d. & $99.9 \pm 0.0$ & n.d. & \\
\hline Testosterone & $0.02 \pm 0.09$ & $0.00 \pm 0.00$ & $99.9 \pm 0.0$ & $99.9 \pm 0.0$ & n.d. & n.d. & \\
\hline \multicolumn{8}{|l|}{ Plasticizer } \\
\hline Bisphenol A & $0.27 \pm 0.45$ & $0.18 \pm 0.40$ & $58.0 \pm 43.7$ & $56.6 \pm 42.9$ & $56.7 \pm 54.0$ & $58.9 \pm 37.8$ & $*$ \\
\hline TCPP & $0.37 \pm 0.89$ & $0.19 \pm 0.14$ & $33.9 \pm 32.9$ & $24.0 \pm 32.6$ & $56.5 \pm 28.0$ & $19.3 \pm 20.6$ & $\dagger$ \\
\hline TBEP & $0.19 \pm 0.25$ & $0.08 \pm 0.14$ & $54.2 \pm 31.2$ & $45.5 \pm 37.3$ & $40.4 \pm 29.3$ & $67.7 \pm 21.4$ & $*, \dagger$ \\
\hline \multicolumn{8}{|l|}{ Preservatives } \\
\hline Methylparaben & $6.88 \pm 8.91$ & $0.01 \pm 0.02$ & $99.7 \pm 0.5$ & $98.5 \pm 0.5$ & $99.7 \pm 0.5$ & $99.8 \pm 0.5$ & $*, \ddagger$ \\
\hline Ethylparaben & $3.35 \pm 9.43$ & $0.00 \pm 0.01$ & $99.4 \pm 1.1$ & $98.8 \pm 0.5$ & $99.4 \pm 0.9$ & $99.8 \pm 1.5$ & $*, \dagger$ \\
\hline Propylparaben & $2.22 \pm 2.60$ & $0.00 \pm 0.01$ & $99.0 \pm 4.7$ & $97.8 \pm 8.0$ & $99.9 \pm 0.4$ & $99.9 \pm 0.8$ & $*$ \\
\hline \multicolumn{8}{|l|}{ Disinfectant } \\
\hline Triclosan & $0.20 \pm 0.47$ & $0.02 \pm 0.04$ & $98.9 \pm 2.5$ & $99.9 \pm 0.0$ & n.d. & $98.4 \pm 2.9$ & $*$ \\
\hline
\end{tabular}




\subsubsection{Overall micropollutants removal efficiency}

The removal of micropollutants by vertECO as a function of HRTs is presented in table 3.2. As previously mentioned, there is very limited literature on the removal of many micropollutants, in particular on EDCs, in greywater matrix. Moreover, greywater treatment by means of wetlands are rare and, in most cases, only comparison with wastewater treatment was possible. No difference in removal efficiency was found as a function of high or low touristic season for the studied PhACs and EDCs $(p>0.05)$.

Extremely high removal efficiencies (> 98\%) were generally observed for acetaminophen, ibuprofen and salicylic acid (Fig.3.2.2.). Similar results were also obtained by HF wetlands treating grey- and wastewater (Ávila et al., 2013; Gattringer et al., 2016; Ranieri et al., 2011). Removal of acetaminophen and ibuprofen is mostly accomplished by biodegradation processes under aerobic conditions (Matamoros et al., 2012; Ranieri et al., 2011), as it is the case of vertECO. Salicylic acid is found to be easily degraded in all surface and subsurface flow systems in high redox potential environments (Hijosa-Valsero et al., 2010). Macrophytes and/ or their root surface associated microorganisms appear to have an impact in the removal of acetaminophen, ibuprofen and salicylic acid, as it has been demonstrated in several studies of planted and unplanted reactors (Ávila et al., 2010; Matamoros and Bayona, 2006; Ranieri et al., 2011; Ternes et al., 2004). In addition, due to its alkaline nature, LECA is a good sorbent for acidic pharmaceutical compounds (such as salicylic acid) through electrostatic interactions (Dordio et al., 2009).

High removal efficiencies could be achieved for atenolol (93\%), diclofenac (88\%) and trimethoprim (91\%). In the case of atenolol an alkaline, positive charged compound, strong sorption can occur through ion exchange with LECA (Dordio et al., 2009). Diclofenac removal in the literature is often marked by inconsistent and contrasting results but mostly associated to biodegradation (Ávila et al., 2013). According to the literature, HF wetlands showed diclofenac degradation up to $52 \%$, while higher removal efficiencies (65-96\%) were only reported in hybrid systems (Hijosa-Valsero et al., 2010). In vertECO the higher removal of diclofenac could be related to the high oxidation status of the wetland (Hijosa-Valsero et al., 2010), probably due to the additional aeration and oxygen release in the rhizosphere by the plant roots of certain species (Stottmeister et al., 2003). Trimethoprim, finally, seems to be easily eliminated in HFCWs by microbial degradation (Hijosa-Valsero et al., 2011). 
Lower removal efficiencies, in the range $50-70 \%$ were observed for ketoprofen, metoprolol, naproxen, iopromide and carbamazepine, while hydrochlorothiazide was only $28 \%$ removed. Ketoprofen has a similar structure to ibuprofen, but is more recalcitrant to degradation due to the keto group and the extended aromatic rings (Camacho-Muñoz et al., 2012; Matamoros et al., 2009). Concerning the chemical structure and the functional groups, similar conclusions can be drawn for naproxen, hydrochlorothiazide and metoprolol. Carbamazepine is usually a very persistent compound and recalcitrant to biodegradation (Matamoros et al., 2009). Here, however an average removal of $56 \%$ was observed, probably due to extreme variability in the influent concentration and/ or sorption capacity of the substrate (Tixier et al., 2003). Finally, negative removal values were obtained only for salbutamol and in some cases for sulfamethoxazole. This could be attributed to release phenomena during the treatment (Anjos et al., 2018), low observed concentrations and high influent variability, or not time adjusted sampling according to the HRT (Roberts and Thomas, 2006).

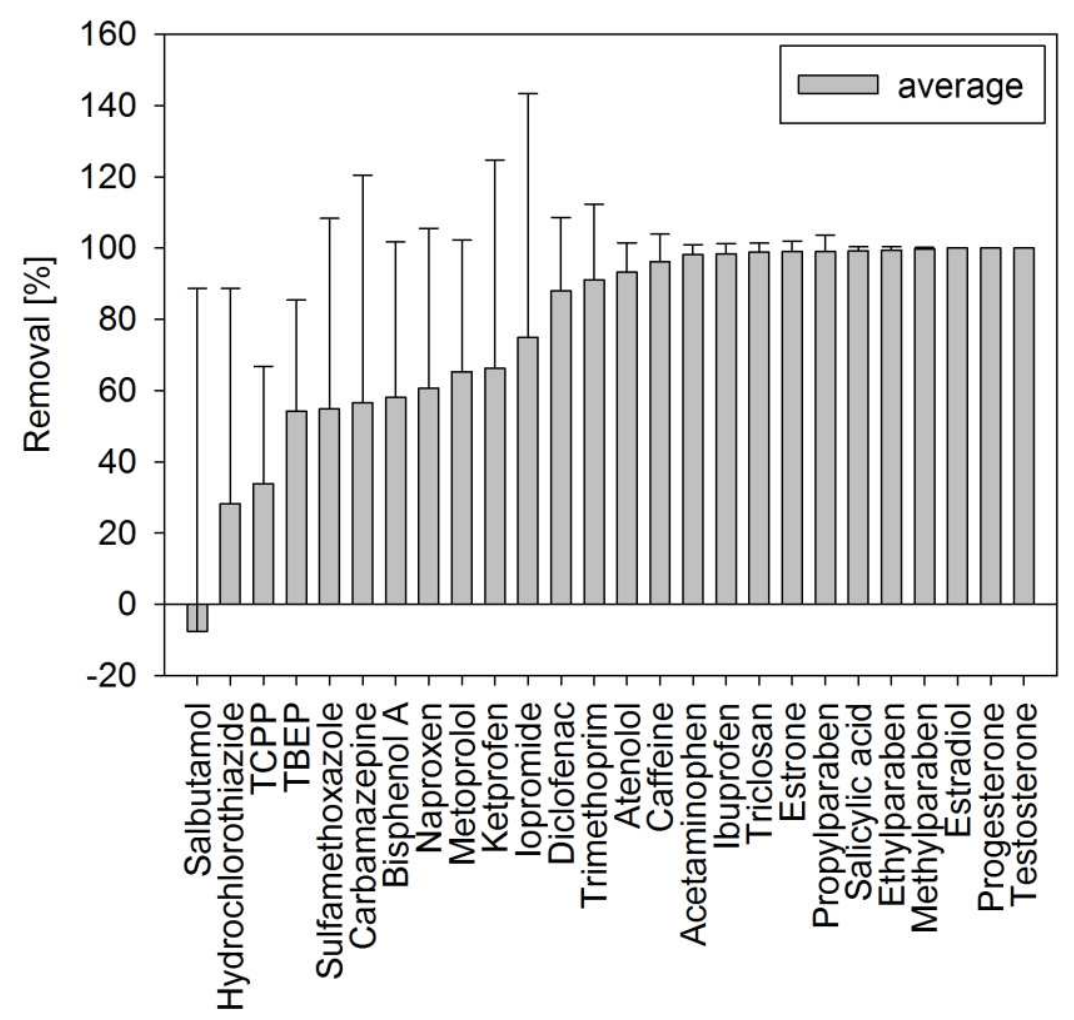

Figure 3.2.2. Total Average (AV) Removal (\%) of micropollutants during long term monitoring 
Regarding the EDCs and related compounds, extremely high removal (> 99\%) were observed for estradiol, progesterone, testosterone, methyl-, ethyl- and propylparaben and high removal (> 96\%) for estrone, caffeine and triclosan. Estrogens and progesterone are reported to be degradable in both, aerobic and anaerobic environments, as well as removed by adsorption (Froehner et al., 2011; Vymazal et al., 2015). A recent study investigated estrone and estradiol under different conditions and observed the benefit of aerobic conditions to degrade these compounds (Dai et al., 2016), which is the case of vertECO due to the artificial aeration. Only little literature is generally available on the removal of estrogen, progesterone and testosterone by means of constructed wetlands. The three preservatives (methyl-, ethyl- and propylparaben) also showed an extremely high removal rate (> 99\%), mostly related to biodegradation processes. Caffeine is commonly an easy biodegradable substance and it is therefore often chosen as a reference compound (Matamoros and Bayona, 2006). Triclosan, mostly used as antibacterial agent for hygiene and personal care products, can be removed by both substrate and plant sorption as well as biodegradation, as previously reported in HF wetlands (Carranza-Diaz et al., 2014; Hijosa-Valsero et al., 2010). Plasticizers like bisphenol A, TCPP and TBEP were characterized by smaller removal (58\%, 34\% and 54\%, respectively). According to the literature, plasticizers higher in the outflow than in the inflow are often reported, but the reason is sometimes still obscure (Ávila et al., 2010). In the present study, however, the lower removal rate of these compounds may be related to some release from plastic parts, valves, pipes and other technical devices.

In terms of water reuse, to be remarked that no legislation is available at European levels regarding the here studied organic micropollutants, although some of them (including estrone and estradiol) are now included in the EU Watch List 2018/840 (EC, 2018). This European Decision states that the listed contaminants have to be monitored across Europe to obtain high quality data on their occurrence, to inform further legislative action, and the present paper contributes in this direction.

\subsubsection{Micropollutants removal under different condition}

Influence of hydraulic retention time (HRT)

As previously mentioned, higher removal efficiencies are usually reported at higher HRTs (Matamoros et al., 2008). Conversely, in the present study, higher removal 
efficiencies were observed for acetaminophen, atenolol and ibuprofen at the lowest HRT $(p<0.05)$ (Fig.3.2.3.), even though with average removal rates always higher than $88 \%$ at all tested HRTs. This could be related to the fact that decreasing HRTs were tested during the experimental periods. Denser root systems and more retained solids in the system were more likely present at lower HRTs. It can be consequently speculated that the high planting density (28 plants per $\mathrm{m}^{2}$ ), the growth of the plants and the increase in root density in the rhizosphere, with consequently extended contact surface between pollutants and plant roots, compensated the decrease in HRT. HRTs had no significant influence on the efficiency of PhACs removal. A similar pattern was observed for EDCs, with no influence of HRT on the removal efficiencies $(p>0.05)$ for most compounds except for ethylparaben, TCPP and TBEP (higher removal at lower HRT).

To be remarked that no data are available in the literature on the correlation between micropollutants removal and HRT in terms of greywater treatment by means of constructed wetlands. Moreover, wetlands for wastewater treatment usually apply higher HRTs (e.g. 3.5 - 5.5 days; Ávila et al., 2010; Carranza-Diaz et al., 2014; Hijosa-Valsero et al., 2010). This confirms the relevance of the results presented here regarding the removal of organic micropollutants with short HRTs (1.0 - 1.9 days, table 2.2), and the resulting reduced needed footprint.

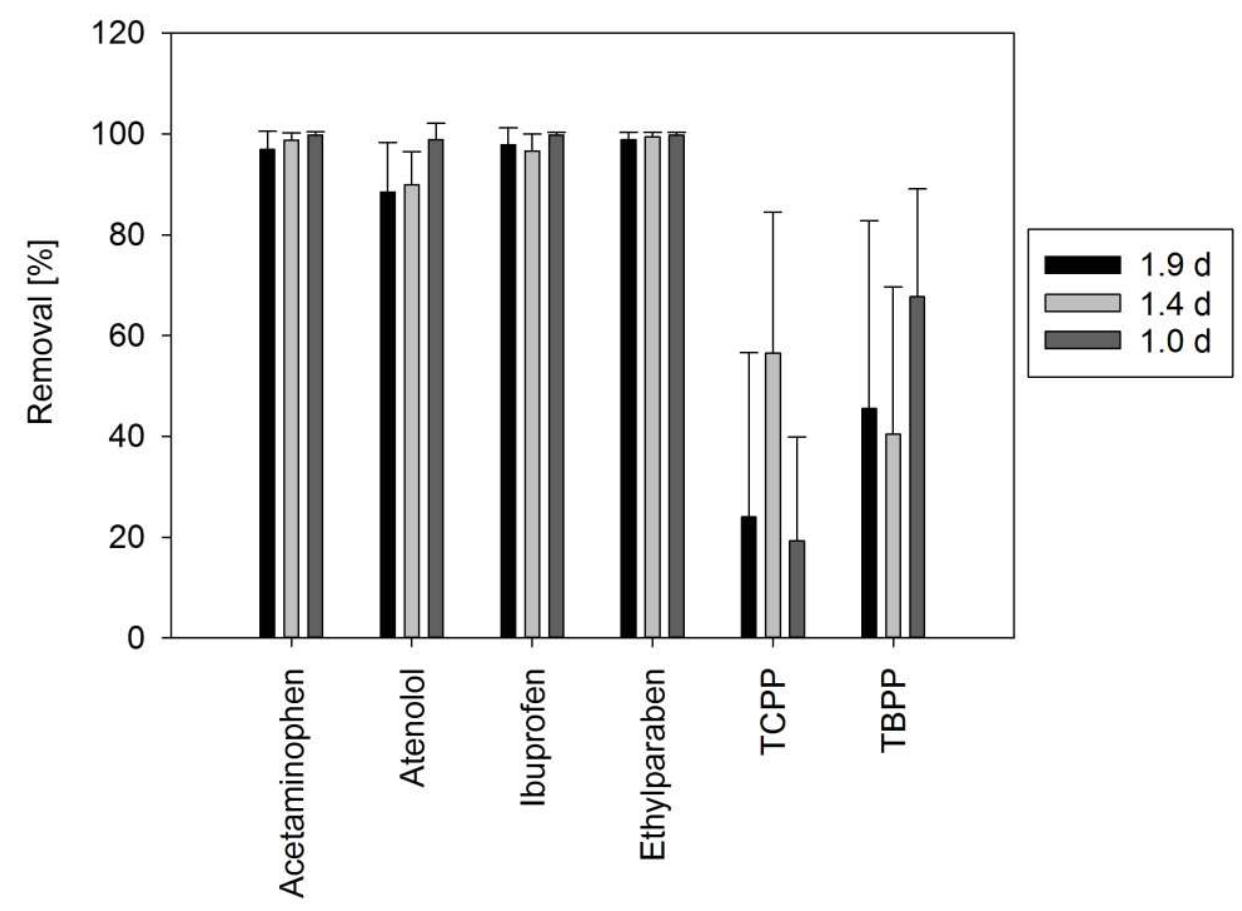


Figure 3.2.3. Micropollutants Average (AV) removal (\%) and STDEV according to the three tested HRTs

\section{Influence of temperature}

With the exception of hydrochlorothiazide for PhACs and methylparaben for EDCs ( $p$ $<0.05$ ), no significant influence of temperature on the removal of micropollutants was observed $(p>0.05)$.

According to the literature, temperature is reported to influence the removal of micropollutants (e.g. caffeine, naproxen and salicylic acid, Hijosa-Valsero et al., 2010). The optimal activity of microorganisms in CWs is favored by warm temperatures of $15-25{ }^{\circ} \mathrm{C}$, which was the case in our study for most of the experimental time. vertECO, in fact, was semi indoor, also due to some tropical plant species. Consequently, the temperature difference among the seasons was limited and the average never below $15^{\circ} \mathrm{C}$ (Table 2.2.), resulting in an overall good and constant performance. Moreover, it is reported that the effect of lower temperature on the removal efficiency is higher in superficial flow than in sub-superficial flow $\mathrm{CW}$ (Verlicchi and Zambello, 2014).

\section{Conclusions}

vertECO was confirmed as an effective nature-based option for decentralized greywater treatment and reuse, meeting the requirements of the Spanish legislation and European draft for water reuse for many purposes.

Extremely high concentrations and variability were observed in the influent greywater in terms of organic micropollutants, most likely due to the low dilution. vertECO confirmed to be highly effective in removing many PhACs and EDCs. Other compounds (ketoprofen, naproxen, carbamazepine, metoprolol, sulfamethoxazole and hydrochlorothiazide) show more persistency and, in the case of bisphenol A, TCPP and TBEP, likely related to the release of plastic valves and technical devices. Higher removal efficiency could be established at lower HRT for TN, TKN, $\mathrm{NH}_{4}{ }^{+}-\mathrm{N}$, acetaminophen, atenolol, ibuprofen, TCPP and TBEP. The increase in root density in the subsurface might have compensated the HRT variance.

Temperature had a limited influence and only correlated with $\mathrm{BOD}_{5}$, hydrochlorothiazide and methylparaben removal; most likely because vertECO was 
semi-indoor and sub-superficial flow.

\section{Acknowledgements}

Authors acknowledge the support from the Economy and Knowledge Department of the Catalan Government through a Consolidated Research Group (ICRA-TECH 2017 SGR 1318) - Catalan Institute for Water Research. Gianluigi Buttiglieri acknowledges the Ramon y Cajal research fellowship (RYC-2014-16754) and the project CTM2017-85385-C2-1-R from the Spanish Ministry of Economy and Competitiveness. Moreover, they acknowledge the support for scientific equipment given by the European Regional Development Fund (FEDER) under the Catalan FEDER Operative Program 2007-2013 and by MINECO according to DA3 ${ }^{\mathrm{a}}$ of the Catalan Statute of Autonomy and to PGE-2010. This study was partially funded under the $7^{\text {th }}$ framework program of the European Union (Grant agreement $N^{\circ}$ 619116). Gratitude also goes to Hotel Samba management and Goran Aleksic for their generous and patient practical support at the test location. Finally, authors would like to thank Sara Insa and Marta Villagrasa for the support in the analytical part and Marc Balcells for the valuable help.

\section{References}

Akratos, C.S., Tsihrintzis, V.A., 2007. Effect of temperature, HRT, vegetation and porous media on removal efficiency of pilot-scale horizontal subsurface flow constructed wetlands. Ecol. Eng. 29, 173-191. https://doi.org/10.1016/j.ecoleng.2006.06.013

Albalawneh, A., Chang, T.-K., Chou, C.-S., Naoum, S., 2016. Efficiency of a Horizontal Sub-Surface Flow Constructed Wetland Treatment System in an Arid Area. Water 8, 51. https://doi.org/10.3390/w8020051

Alcalde-Sanz, L., Gawlik, B.M., 2017. Minimum quality requirements for water reuse in agricultural irrigation and aquifer recharge - Towards a water reuse regulatory instrument at EU level, EUR 28962 EN,. Publ. Off. Eur. Union Luxemb. https://doi.org/10.2760/887727

Andersen, H.R., Lundsbye, M., Wedel, H.V., Eriksson, E., Ledin, A., 2007. Estrogenic personal care products in a greywater reuse system. Water Sci. Technol. 56(12), 4549. https://doi.org/10.2166/wst.2007.821

Anjos, M.L., Isique, W.D., Albertin, L.L., Matsumoto, T., Henares, M.N.P., 2018. Parabens Removal from Domestic Sewage by Free-Floating Aquatic Macrophytes. Waste Biomass Valorization. https://doi.org/10.1007/s12649-018-0245-6

APHA, 1998. Standard Methods for the Examination of Water and Wastewater, 22nd Edition, twentieth edition. ed. American Public Health Association, Washington D.C. 
Avery, L.M., Frazer-Williams, R.A.D., Winward, G., Shirley-Smith, C., Liu, S., Fayyaz, A.M., Jefferson, B., 2007. Constructed wetlands for grey water treatment. Ecohydrol. Hydrobiol. 7, 91-200. https://doi.org/10.1016/S1642-3593(07)70101-5

Ávila, C., Pedescoll, A., Matamoros, V., Bayona, J.M., García, J., 2010. Capacity of a horizontal subsurface flow constructed wetland system for the removal of emerging pollutants: An injection experiment. Chemosphere 81, 1137-1142. https://doi.org/10.1016/j.chemosphere.2010.08.006

Ávila, C., Reyes, C., Bayona, J.M., García, J., 2013. Emerging organic contaminant removal depending on primary treatment and operational strategy in horizontal subsurface flow constructed wetlands: Influence of redox. Water Res. 47, 315-325. https://doi.org/10.1016/j.watres.2012.10.005

Buttiglieri, G., Knepper, T.P., 2008. Removal of Emerging Contaminants in Wastewater Treatment: Conventional Activated Sludge Treatment, in: Barceló, D., Petrovic, M. (Eds.), Emerging Contaminants from Industrial and Municipal Waste. Springer Berlin Heidelberg, Berlin, Heidelberg, pp. 1-35. https://doi.org/10.1007/698_5_098

Camacho-Muñoz, D., Martín, J., Santos, J.L., Aparicio, I., Alonso, E., 2012. Effectiveness of Conventional and Low-Cost Wastewater Treatments in the Removal of Pharmaceutically Active Compounds. Water. Air. Soil Pollut. 223, 2611-2621. https://doi.org/10.1007/s11270-011-1053-9

Carballa, C., Alvarino, T., Buttiglieri, G., Choubert, J.M., Pons, M.N., 2017. Innovative primary and secondary sewage treatment technologies for organic micropollutants abatement. Innovative Wastewater Treatment and Resource Recovery Technologies: Impacts on Energy, Economy and Environment.

Carranza-Diaz, O., Schultze-Nobre, L., Moeder, M., Nivala, J., Kuschk, P., Koeser, H., 2014. Removal of selected organic micropollutants in planted and unplanted pilot-scale horizontal flow constructed wetlands under conditions of high organic load. Ecol. Eng. 71, 234-245. https://doi.org/10.1016/j.ecoleng.2014.07.048

Dai, Y., A, D., Yang, Y., Tam, N.F., Tai, Y.-P., Tang, X.-Y., 2016. Factors Affecting Behavior of Phenolic Endocrine Disruptors, Estrone and Estradiol, in Constructed Wetlands for Domestic Sewage Treatment. Environ. Sci. Technol. 50, 11844-11852. https://doi.org/10.1021/acs.est.6b02026

Dixon, Butler D., Fewkes A., Robinson M., 1999. Measurement and modelling of quality changes in stored untreated grey water. Urban Water 1, 293-306. https://doi.org/10.1016/S1462-0758(00)00031-5

Dordio, A., Pinto, J., Barrocas Dias, C., Pinto, A.P., Palace Carvalho, A.J., Teixeira, D.M., 2009. Atenolol removal in microcosm constructed wetlands. Int. J. Environ. Anal. Chem. 89, 835-848. https://doi.org/10.1080/03067310902962502

EC, 2018. Commission Implementing Decision (EU) 2018/840 of 5 June 2018 Establishing a Watch List of Substances for Union-wide Monitoring in the Field of Water Policy Pursuant to Directive 2008/105/EC of the European Parliament and of the Council and Repealing Commission Implementing Decision (EU) 2015/495 (Notified Under Document C (2018) 3362). Off. J. Eur. Union. https://doi.org/Retrieved from https://eur-lex.europa.eu/legalcontent/EN/TXT/PDF/?uri=CELEX:32018D0840\&from=EN

EC, 2015. Commission Implementing Decision (EU) 2015/495 of 20 March 2015 establishing a watch list of substances for Union-wide monitoring in the field of water policy pursuant to Directive 2008/105/EC of the European Parliament and of the Council.

EC, 2012. Impact Assessment of the Communication:'A Blueprint to Safeguard Europe's Water Resources'(SWD(2012) 382 final). 
Eriksson, E., Auffarth, K., Henze, M., Ledin, A., 2002. Characteristics of grey wastewater. Urban Water 4, 85-104. https://doi.org/10.1016/S1462-0758(01)00064-4

Froehner, S., Piccioni, W., Machado, K.S., Aisse, M.M., 2011. Removal Capacity of Caffeine, Hormones, and Bisphenol by Aerobic and Anaerobic Sewage Treatment. Water. Air. Soil Pollut. 216, 463-471. https://doi.org/10.1007/s11270-010-0545-3

Gabarda-Mallorquí, A., Garcia, X., Ribas, A., 2017. Mass tourism and water efficiency in the hotel industry: A case study. Int. J. Hosp. Manag. 61, 82-93. https://doi.org/10.1016/j.ijhm.2016.11.006

Gattringer, H., Claret, A., Radtke, M., Kisser, J., Zraunig, A., Rodriguez-Roda, I., Buttiglieri, G., 2016. Novel vertical ecosystem for sustainable water treatment and reuse in tourist resorts. Int. J. Sustain. Dev. Plan. 11, 263-274. https://doi.org/10.2495/SDP-V11-N3263-274

Gorga, M., Petrovic, M., Barceló, D., 2013. Multi-residue analytical method for the determination of endocrine disruptors and related compounds in river and waste water using dual column liquid chromatography switching system coupled to mass $\begin{array}{lllll}\text { spectrometry. } & \text { J. } & \text { Chromatogr. } & \text { A } & \text { 57-66. }\end{array}$ https://doi.org/10.1016/j.chroma.2013.04.028

Gössling, S., Peeters, P., Hall, C.M., Ceron, J.-P., Dubois, G., Lehmann, L.V., Scott, D., 2012. Tourism and water use: Supply, demand, and security. An international review. Tour. Manag. 33, 1-15. https://doi.org/10.1016/j.tourman.2011.03.015

Gros, M., Rodríguez-Mozaz, S., Barceló, D., 2012. Fast and comprehensive multi-residue analysis of a broad range of human and veterinary pharmaceuticals and some of their metabolites in surface and treated waters by ultra-high-performance liquid chromatography coupled to quadrupole-linear ion trap tandem mass spectrometry. J. Chromatogr. A 1248, 104-121. https://doi.org/10.1016/j.chroma.2012.05.084

Gulyas, H., Reich, M., Otterpohl, R., 2011. Organic micropollutants in raw and treated greywater: a preliminary investigation. Urban Water J. 8, 29-39. https://doi.org/10.1080/1573062X.2010.528435

Hernández Leal, L., 2010. Removal of micropollutants from grey water: combining biological and physical/chemical processes.

Hernández Leal, L., Vieno, N., Temmink, H., Zeeman, G., Buisman, C.J.N., 2010. Occurrence of Xenobiotics in Gray Water and Removal in Three Biological Treatment Systems. Environ. Sci. Technol. 44, 6835-6842. https://doi.org/10.1021/es101509e

Hijosa-Valsero, M., Fink, G., Schlüsener, M.P., Sidrach-Cardona, R., Martín-Villacorta, J., Ternes, T., Bécares, E., 2011. Removal of antibiotics from urban wastewater by constructed wetland optimization. Chemosphere 83, 713-719. https://doi.org/10.1016/j.chemosphere.2011.02.004

Hijosa-Valsero, M., Matamoros, V., Sidrach-Cardona, R., Mart??n-Villacorta, J., B??cares, E., Bayona, J.M., 2010. Comprehensive assessment of the design configuration of constructed wetlands for the removal of pharmaceuticals and personal care products from urban wastewaters. Water Res. 44, 3669-3678. https://doi.org/10.1016/j.watres.2010.04.022

Jefferson, B., Burgess, J.E., Pichon, A., Harkness, J., Judd, S.J., 2001. Nutrient addition to enhance biological treatment of greywater. Water Res. 35, 2702-2710.

Jefferson, B., Palmer, A., Jeffrey, P., Stuetz, R., Judd, S., 2004. Grey water characterisation and its impact on the selection and operation of technologies for urban reuse. Water Sci. Technol. 50(2), 157-164. 
Kozak, M., Rimmington, M., 2000. Tourist Satisfaction with Mallorca, Spain, as an OffSeason Holiday Destination. J. Travel Res. 38, 260-269. https://doi.org/10.1177/004728750003800308

Langergraber, G., 2005. The role of plant uptake on the removal of organic matter and nutrients in subsurface flow constructed wetlands: a simulation study. Water Sci. Technol. 51(9), 213-223. https://doi.org/10.2166/wst.2005.0322

Lee, C., Fletcher, T.D., Sun, G., 2009. Nitrogen removal in constructed wetland systems. Eng. Life Sci. 9, 11-22. https://doi.org/10.1002/elsc.200800049

Loos, R., Marinov, D., Sanseverino, I., Napierska, D., Lettieri, T., 2018. Review of the 1st Watch List under the Water Framework Directive and recommendations for the 2nd Watch List, EUR 29173 EN, Publications Office of the European Union. https://doi.org/10.2760/614367

Luo, Y., Guo, W., Ngo, H.H., Nghiem, L.D., Hai, F.I., Zhang, J., Liang, S., Wang, X.C., 2014. A review on the occurrence of micropollutants in the aquatic environment and their fate and removal during wastewater treatment. Sci. Total Environ. 473-474, 619-641. https://doi.org/10.1016/j.scitotenv.2013.12.065

Masi, F., Martinuzzi, N., 2007. Constructed wetlands for the Mediterranean countries: hybrid systems for water reuse and sustainable sanitation. Desalination 215, 44-55. https://doi.org/10.1016/j.desal.2006.11.014

Matamoros, V., Arias, C., Brix, H., Bayona, J.M., 2009. Preliminary screening of small-scale domestic wastewater treatment systems for removal of pharmaceutical and personal care products. Water Res. 43, 55-62. https://doi.org/10.1016/j.watres.2008.10.005

Matamoros, V., Arias, C.A., Nguyen, L.X., Salvadó, V., Brix, H., 2012. Occurrence and behavior of emerging contaminants in surface water and a restored wetland. Chemosphere 88, 1083-1089. https://doi.org/10.1016/j.chemosphere.2012.04.048

Matamoros, V., Bayona, J.M., 2006a. Elimination of Pharmaceuticals and Personal Care Products in Subsurface Flow Constructed Wetlands. Environ. Sci. Technol. 40, 58115816. https://doi.org/10.1021/es0607741

Matamoros, V., Bayona, J.M., 2006b. Elimination of Pharmaceuticals and Personal Care Products in Subsurface Flow Constructed Wetlands. Environ. Sci. Technol. 40, 58115816. https://doi.org/10.1021/es0607741

Matamoros, V., Caselles-Osorio, A., García, J., Bayona, J.M., 2008. Behaviour of pharmaceutical products and biodegradation intermediates in horizontal subsurface flow constructed wetland. A microcosm experiment. Sci. Total Environ. 394, 171176. https://doi.org/10.1016/j.scitotenv.2008.01.029

Moreno-González, R., Rodriguez-Mozaz, S., Gros, M., Barceló, D., León, V.M., 2015. Seasonal distribution of pharmaceuticals in marine water and sediment from a mediterranean coastal lagoon (SE Spain). Environ. Res. 138, 326-344. https://doi.org/10.1016/j.envres.2015.02.016

Ramprasad, C., Philip, L., 2016. Surfactants and personal care products removal in pilot scale horizontal and vertical flow constructed wetlands while treating greywater. Chem. Eng. J. 284, 458-468. https://doi.org/10.1016/j.cej.2015.08.092

Ramprasad, C., Smith, C.S., Memon, F.A., Philip, L., 2017. Removal of chemical and microbial contaminants from greywater using a novel constructed wetland: GROW. Ecol. Eng. 106, 55-65. https://doi.org/10.1016/j.ecoleng.2017.05.022

Ranieri, E., Verlicchi, P., Young, T.M., 2011. Paracetamol removal in subsurface flow constructed wetlands. J. Hydrol. 404, 130-135. https://doi.org/10.1016/j.jhydrol.2011.03.015

RD, 1620. REAL DECRETO 1620/2007, de 7 de diciembre, por el que se establece el régimen jurídico de la reutilización de las aguas depuradas, BOE 294 46932-46946 
(2005).

Retrieved

from

http://www.boe.es/aeboe/consultas/bases datos/doc.php?id=BOE-A-2008-18947 22.

Revitt, D.M., Eriksson, E., Donner, E., 2011. The implications of household greywater treatment and reuse for municipal wastewater flows and micropollutant loads. Water Res. 45, 1549-60. https://doi.org/10.1016/j.watres.2010.11.027

Roberts, P., Thomas, K., 2006. The occurrence of selected pharmaceuticals in wastewater effluent and surface waters of the lower Tyne catchment. Sci. Total Environ. 356, 143-153. https://doi.org/10.1016/j.scitotenv.2005.04.031

Stottmeister, U., Wießner, A., Kuschk, P., Kappelmeyer, U., Kästner, M., Bederski, O., Müller, R.A., Moormann, H., 2003. Effects of plants and microorganisms in constructed wetlands for wastewater treatment. Biotechnol. Adv. 22, 93-117. https://doi.org/10.1016/j.biotechadv.2003.08.010

Ternes, T.A., Joss, A., Siegrist, H., 2004. Peer reviewed: scrutinizing pharmaceuticals and personal care products in wastewater treatment. ACS Publications.

Tixier, C., Singer, H.P., Oellers, S., Müller, S.R., 2003. Occurrence and Fate of Carbamazepine, Clofibric Acid, Diclofenac, Ibuprofen, Ketoprofen, and Naproxen in Surface Waters. Environ. Sci. Technol. 37, 1061-1068. https://doi.org/10.1021/es025834r

Verlicchi, P., Zambello, E., 2014. How efficient are constructed wetlands in removing pharmaceuticals from untreated and treated urban wastewaters? A review. Sci. Total Environ. 470-471, 1281-1306. https://doi.org/10.1016/j.scitotenv.2013.10.085

Vymazal, J., 2005. Horizontal sub-surface flow and hybrid constructed wetlands systems for wastewater treatment. Ecol. Eng. 25, 478-490. https://doi.org/10.1016/j.ecoleng.2005.07.010

Vymazal, J., 2002. The use of sub-surface constructed wetlands for wastewater treatment in the Czech Republic : 10 years experience 18, 633-646.

Vymazal, J., Březinová, T., Koželuh, M., 2015. Occurrence and removal of estrogens, progesterone and testosterone in three constructed wetlands treating municipal sewage in the Czech Republic. Sci. Total Environ. 536, 625-631. https://doi.org/10.1016/j.scitotenv.2015.07.077 